\title{
Parvovirus infection in a family associated with aplastic crisis in an affected sibling pair with hereditary spherocytosis
}

\author{
DH GREEN,* AJ BELLINGHAM,* MJ ANDERSON $\dagger$ \\ From the *Royal Liverpool Hospital, Liverpool, and the †Department of Medical Microbiology, King's \\ College Hospital, London SE5
}

SUMMARY There have been many reports of aplastic crisis preceded by a febrile illness in hereditary haemolytic anaemias. Recent research has shown that the human parvovirus may be a causative agent. We report on an adult sibling pair with hereditary spherocytosis who presented in aplastic crisis after a febrile illness. Both had evidence of recent parvovirus infection, shown by the presence of IgM class specific antibody in their sera. The children of one of the sibling pair, one of whom has hereditary spherocytosis but no chronic haemolysis, showed similar evidence of acute parvovirus infection.

In 1975 Cossart et al $^{1}$ reported finding a novel virus infecting man. The short lived viraemia was followed by the appearance of specific antibody. The virus is now known to be a human parvovirus. ${ }^{2}$ Infection with human parvovirus is common and some $60 \%$ of blood donors have viral antibodies, ${ }^{3}$ which occur most commonly in children of primary school age. ${ }^{4}$ The method of transmission of human parvovirus remains obscure; parvovirus like agents have been found in stool specimens but these are antigenically different from the human parvovirus found in blood. ${ }^{5}$ As yet human parvovirus has not been detected in respiratory secretions, although Anderson et al $^{6}$ reported an association between respiratory tract infections and primary infection with human parvovirus in four children with homozygous sickle cell disease.

Human parvovirus has been incriminated as the causative agent in a febrile illness, ${ }^{57}$ erythema infectiosum (fifth disease), ${ }^{8}$ and aplastic crisis in hereditary haemolytic anaemias. Several authors report the association between human parvovirus and aplastic crisis in sickle cell disease $e^{9-12}$ and there have been reports of human parvovirus associated aplasia in thalassaemia intermedia ${ }^{13}$ and pyruvate kinase deficiency. ${ }^{14}$ In a retrospective study of clinical data, Mortimer $^{15}$ concluded that human parvovirus was probably responsible for aplastic crisis occurring in hereditary spherocytosis. Human parvovirus has

Accepted for publication 11 July 1984 since been serologically linked to aplastic crisis occurring in paediatric patients with hereditary spherocytosis. ${ }^{1216}$

We report acute human parvovirus infection in an adult sibling pair and in the two children of one of them. Both adults presented in aplastic crisis; in one hereditary spherocytosis had been diagnosed in childhood after an aplastic crisis in her aunt. The second adult and one of the two children were newly diagnosed as hereditary spherocytosis after the viral illness.

\section{Case reports}

\section{PATIENT 1}

A 33 year old woman was admitted to the Royal Liverpool Hospital on 4 January 1984. She gave a six day history of a febrile illness with abdominal pains, swelling of the hands, and general fatigue, and a two day history of "banging" headache, palpitations, and dizziness on standing. Hereditary spherocytosis had been diagnosed in childhood after an aplastic crisis in her aunt. The patient was advised to have a splenectomy at that time but this was declined.

On examination the patient was ill, very pale, slightly jaundiced, and feverish $\left(38.0^{\circ} \mathrm{C}\right)$. The pulse was 120 beats $/ \mathrm{min}$ and was feeble, and there was an ejection systolic murmur at the apex. The spleen was palpable $4 \mathrm{~cm}$ below the left costal margin.

The blood count was as follows: haemoglobin 
concentration $3.7 \mathrm{~g} / \mathrm{dl}$; packed cell volume $10.6 \%$; red blood cell count $1.28 \times 10^{12} / \mathrm{l}$; white cell count $8.5 \times 10^{9} / 1$; platelet count $196 \times 10^{9} / 1$. The blood film showed numerous spherocytes; no reticulocytes were seen. The result of a direct Coombs test was negative and the osmotic fragility was increased. The serum bilirubin concentration was $32 \mu \mathrm{mol} / \mathrm{l}$.

The patient was transfused and made a rapid recovery. Seven days after admission the blood count was as follows: haemoglobin concentration $13.6 \mathrm{~g} / \mathrm{dl}$; packed cell volume $38.6 \%$; red blood cell count $4.34 \times 10^{12} / 1$; white cell count $9.2 \times 10^{9} / \mathrm{l}$; and platelet count $194 \times 10^{9} / 1$. One month after admission the haemoglobin concentration had fallen to $11.0 \mathrm{~g} / \mathrm{dl}$ with a reticulocyte count of $17 \%$.

\section{PATIENT 2}

A 28 year old man, the brother of patient 1 , was admitted to the Royal Liverpool Hospital on 22 January 1984. He gave a seven day history of lethargy, weakness, shivering, and muscular pains in both calves and a more recent history of headache, palpitation, and dizziness.

On examination he was pale but otherwise was not in acute distress. The tip of the spleen was palpable below the left costal margin. The blood count was as follows: haemoglobin concentration $7.3 \mathrm{~g} / \mathrm{dl}$; packed cell volume $20.7 \%$; red blood cell count $2 \cdot 15 \times 10^{12} / \mathrm{l}$; white cell count $11.5 \times 10^{9} / \mathrm{l}$; platelet count $274 \times 10^{9} / 1$. The blood film showed many spherocytes and the reticulocyte count was $3 \%$. The result of a direct Coombs test was negative and the osmotic fragility increased. The serum bilirubin concentration was $10 \mu \mathrm{mol} / \mathrm{l}$.

The patient was transfused and made a rapid recovery. The haematological findings in this patient are consistent with a diagnosis of hereditary spherocytosis. Three months after admission the haemoglobin concentration was $15.2 \mathrm{~g} / \mathrm{dl}$ with a reticulocyte count of $11 \%$.
PATIENTS 3 AND 4

These were the five and 10 year old sons of patient 1. Both developed a febrile illness two days before the onset of symptoms in their mother. They were feverish, complained of pains in the abdomen and lower legs, and vomited on several occasions. Medical advice was sought.

Subsequent haematological investigations showed patient 3 to have hereditary spherocytosis with a steady state haemoglobin concentration of $12 \cdot 2 \mathrm{~g} / \mathrm{dl}$ and reticulocyte count of $1 \%$. Patient 4 had no findings indicating hereditary spherocytosis.

\section{Methods and results}

Serum specimens from each of the members of the family, in three households, were examined for parvovirus specific IgM by antibody capture radioimmunoassay. ${ }^{3}$ Serum specimens from family members who had remained well were also examined for parvovirus specific IgG in an analogous test. ${ }^{3}$

The results are summarised in the Table. Patients $1,2,3$, and 4 had evidence of recent infection with human parvovirus. Patients 5 and 7 had only parvovirus specific IgG, suggesting infection with human parvovirus at some previous date. Patient 6 had no evidence of infection with this virus.

\section{Discussion}

It seems likely that human parvovirus caused aplastic crisis in these two patients with hereditary spherocytosis. Patient 3 has hereditary spherocytosis and evidence of recent human parvovirus infection, but did not present in aplastic crisis, presumably because, unlike patients 1 and 2 , he did not have appreciable haemolysis.

Patients $1,3,4$, and 5 are members of the same household. Patients 1,3 , and 4 all became ill at about the same time, and each had serological evi-

\section{Haematological and virological data}

\begin{tabular}{|c|c|c|c|c|c|c|}
\hline Patient & Age (yr) & $\begin{array}{l}\text { Hereditary } \\
\text { spherocytosis }\end{array}$ & $\begin{array}{l}\text { Date of onset of } \\
\text { illness }\end{array}$ & $\begin{array}{l}\text { Date of serum } \\
\text { specimen }\end{array}$ & $\begin{array}{l}\text { Parvovirus specific } \\
\text { IgM } \\
\text { (Arbitary units) }\end{array}$ & $I g G$ \\
\hline $\begin{array}{l}1 \\
2 \\
3 \\
4 \\
5 \\
6 \\
7\end{array}$ & $\begin{array}{r}33 \\
28 \\
5 \\
10 \\
33 \\
24 \\
60\end{array}$ & $\begin{array}{l}+ \\
+ \\
+ \\
- \\
- \\
+\end{array}$ & $\begin{array}{l}29.12 .83 \\
15.01 .84 \\
27.12 .83 \\
27.12 .83 \\
\text { Remained well } \\
\quad, \quad, \quad, \\
\quad, \quad,\end{array}$ & $\begin{array}{l}11.1 .84 \\
27.1 .84 \\
27.1 .84 \\
27.1 .84 \\
21.2 .84 \\
27.1 .84 \\
27.1 .84\end{array}$ & $\begin{array}{r}>33 \\
>33 \\
>33 \\
9.8 \\
<0.28 \\
<0.28 \\
<0.28\end{array}$ & $\begin{array}{c}3.8 \\
<0.25 \\
23\end{array}$ \\
\hline
\end{tabular}

Patients 1, 3, 4, and 5 are members of the same household.

Patients 2 and 7 are members of the second household.

Patient 7 is the mother of patients 1,2 , and 6 .

Patient 6 is the brother of patient 2; he lives alone. 
dence of recent parvovirus infection. It is likely that these three patients acquired the infection from a common, unidentified source. The father of this household, patient 5, remained well; the presence of parvovirus specific IgG in the absence of specific IgM suggests previous infection with this virus and immunity at the present time.

Patient 2 had stayed overnight with the above household some $12 \mathrm{~h}$ before the onset of illness in patient 1. Eighteen days later he became ill and serological evidence of recent parvovirus infection was found in a serum specimen obtained 12 days later. His mother, patient 7, a member of the same household, remained well; she, like her son in law, patient 5, had evidence of previous infection. Patient 6 is the brother of patient 2 and, although susceptible to human parvovirus infection, he remained well. He lives alone and had no close contact with the family during their illness. The human parvovirus attack rate among susceptible contacts was thus $100 \%$ in these households.

Aplastic crisis have been reported in both acquired and hereditary haemolytic anaemias. They have in common a shortened red cell survival so that aplasia in the bone marrow is rapidly reflected by a fall in haemoglobin concentration. One hypothesis is that erythroid aplasia occurs due to direct infection of erythroid precursors with the virus. Serjeant $e a^{10}$ commented that it is possible that aplasia occurs in normal people but because of their long red cell survival and the self limiting and short duration of the aplasia such episodes would generally pass unnoticed. These factors probably explain why patient 3 did not present in aplastic crisis; his steady state haematological indices indicated no chronic haemolysis, so that a short episode of erythroid aplasia would not cause appreciable anaemia.

In the absence of virus recovered from cases of erythema infectiosum it has not so far been possible to compare parvovirus from cases of aplastic crisis and fifth disease. Although none of the cases described here reported the appearance of a rash, it is of interest to note that patient 1 complained of swollen joints, a common complication in adult cases of erythema infectiosum. ${ }^{17}$ Attempts to grow human parvovirus in tissue culture are in progress. ${ }^{18}$ Successful culture may lead to the development of a vaccine to protect susceptible children and adults from the potentially fatal effects of human parvovirus infection.

\section{References}

' Cossart YE, Field AM, Cant B, Widdows D. Parvovirus-like particles in human sera. Lancet 1975; i: 72-3.

${ }^{2}$ Summers J, Jones SE, Anderson MJ. Characterisation of the genome of the agent of erythrocyte aplasia permits its classification as a human parvovirus. J Gen Virol 1983;64:2527-8.

${ }^{3}$ Cohen B, Mortimer PP, Pereira MS. Diagnostic assays with monoclonal antibodies for the human serum parvovirus-like virus (SPLV). J Hyg 1983;91:113-5.

${ }^{4}$ Edwards JMP, Kessel I, Gardner SD, et al. The search for a characteristic illness in children with serological evidence of viral or toxoplasma infection. Journal of Infection 1981; 3:316-20.

5 Paver WK, Clarke SKR. Comparison of human faecal and serum parvo-like viruses. J Clin Microbiol 1976;4:67-70.

- Anderson MJ, Davis LR, Hodgson J, et al. The occurrence of infection with a parvovirus-like agent in children with sickle cell anaemia during a two year period. J Clin Pathol 1982; 35: 744-9.

${ }^{7}$ Schneerson JM, Mortimer PP, Vandervelde EM. Febrile illness due to a parvovirus. $\mathrm{Br}$ Med J 1980;280:1580.

${ }^{*}$ Anderson MJ, Jones SE, Fisher-Hoch SP, et al. Human parvovirus, the cause of erythema infectiosum (Fifth disease)? Lancet 1983;i: 1378.

' Pattison JR, Jones SE, Hodgson J, et al. Parvovirus infections and hypoplastic crisis in sickle cell anaemia. Lancet 1981;1:664-5.

10 Serjeant GR, Topley JM, Mason K, et al. Outbreak of aplastic crisis in sickle cell anaemia associated with parvovirus-like agent. Lancet 1981;ii:595-7.

"Anderson MJ, Davis LR, Jones SE, Pattison JR, Serjeant GR. The development and use of an antibody capture radioimmunoassay for specific IgM to a human parvovirus-like agent. J Hyg (Lond) 1982;88:309-24.

12 Evans JPM, Rossiter MA, Kumaran TO, Marsh GW, Mortimer PP. Human parvovirus aplasia: case due to cross infection in a ward. $\mathrm{Br}$ Med J 1984;288:681.

${ }^{13}$ Rao KRP, Patel AR, Anderson MJ, Hodgson J, Jones SE, Pattison JR. Infection with parvovirus-like virus and aplastic crisis in chronic haemolytic anaemia. Ann Int Med 1983;98:930-2.

${ }_{14}$ Duncan JR, Potter CG, Cappellini MD, Anderson MJ, Weatherall DJ. Aplastic crisis due to parvovirus infection with pyruvate kinase deficiency. Lancet 1983;ii: 14.

is Mortimer PP. Hypothesis: the aplastic crisis of hereditary spherocytosis is due to a single transmissible agent. $J$ Clin Pathol 1983;36:445-8.

${ }^{16}$ Kelleher JF, Luban NLC, Mortimer PP, Kamimura T. Human serum "parvovirus": a specific cause of aplastic crisis in children with hereditary spherocytosis. J Paediatr 1983; 102:720-2.

17 Ager EA, Chin TDY, Poland JD. Epidemic erythema infectiosum. $N$ Engl J Med 1966;275: 1326.

${ }^{18}$ Anderson MJ. Special article: The emerging story of the human parvovirus-like agent. J Hyg 1982;89:1-8.

Requests for reprints to: Professor AJ Bellingham, The University Department of Haematology, Duncan Building, Royal Liverpool Hospital, Prescot Street, PO Box 147, Liverpool L69 38X, England. 